\title{
THERAPEUTIC LISTENING IN CLINICAL MENTAL HEALTH CARE NURSING
}

\author{
Deivson Wendell da Costa Lima1, Alcivan Nunes Vieira², Lia Carneiro Silveira ${ }^{3}$
}

\begin{abstract}
${ }^{1}$ M.Sc. in Health Clinical Care. Nursing Professor at the Universidade Estadual do Rio Grande do Norte and Universidade Potiguar. Mossoró, Rio Grande do Norte, Brazil. E-mail: deivsonwendell@hotmail.com

2 Doctoral student at the Nursing Clinical Care and Health Graduate Program of the Universidade Estadual do Ceará (UECE). Fortaleza, Ceará, Brazil. E-mail: alcivannunes@uern.br

${ }^{3}$ Ph.D. in Nursing. Professor at the Nursing Clinical Care and Health Graduate Program of the UECE. Fortaleza, Ceará, Brazil. E-mail: silveiralia@gmail.com
\end{abstract}

\begin{abstract}
Research with the aim to understand the conception of therapeutic listening in clinical mental health care nursing. Qualitative study carried out with nine nurses inserted into mental health services. Data were generated by semi-structured interviews and assessed by Michel Pechêux's discourse analysis. The research identified that the listening process is devoid of its therapeutic potential. It is only conceived as a means to obtain information on the subject in psychological distress, a practice that, in summary, is specifically correlated to objectified signs and symptoms at the patient's body. Occasionally, such practice is guided by a psychosocial framework. The listening practice is not in harmony with the principles of the psychiatric reform, as it does not allow for the inclusion of the subject in the care process, and even disregards the patient's speech as an expression of his existence-suffering. Although it contains elements of the psychosocial framework, the listening practice is actually limited to addressing the mental suffering, with no recognition whatsoever of the suffering individual.
\end{abstract}

DESCRIPTORS: Nursing. Mental health. Mental health services.

\section{A ESCUTA TERAPÊUTICA NO CUIDADO CLÍNICO DE ENFERMAGEM EM SAÚDE MENTAL}

RESUMO: Pesquisa que visou compreender a concepção da escuta terapêutica no cuidado clínico de enfermagem em saúde mental. Estudo de abordagem qualitativa, realizado com nove enfermeiros inseridos nos serviços de saúde mental. Os dados foram produzidos através de entrevistas semiestruturadas e analisados pela análise do discurso de Michel Pechêux. Identificou-se que a escuta está destituída do seu potencial terapêutico; é concebida como meio para se obter informações sobre o sujeito em sofrimento psíquico que, em síntese, correspondem aos sinais e sintomas objetificados no corpo. Em alguns momentos, essa prática é norteada pelo referencial psicossocial. A prática da escuta destoa dos princípios da Reforma Psiquiátrica, pois não possibilita a inserção do sujeito no processo de cuidar e desconsidera a sua fala enquanto expressão da sua existência-sofrimento. Apesar de conter elementos do referencial psicossocial, na prática, a escuta se limita a abordar o sofrimento psíquico sem reconhecer o sujeito que sofre.

DESCRITORES: Enfermagem. Saúde mental. Serviços de saúde mental.

\section{TERAPIA DE LA ESCUCHA EN CUIDADOS DE ENFERMERÍA CLÍNICA EN SALUD MENTAL}

RESUMEN: Investigación destinada a comprender el diseño de la atención clínica de escucha terapéutica en enfermería de salud mental. Un estudio cualitativo realizado con nueve enfermeras insertados en los servicios de salud mental. Los datos se han generado a través de entrevistas semi-estructuradas y analizados por el análisis del discurso de Michel Pechêux. Se identificó que escucha está desprovista de su potencial terapéutico, se concibe como un medio para obtener información sobre el tema en los trastornos psicológicos que, en definitiva, corresponde a los signos y síntomas del cuerpo objetivado. En un momento esta práctica se guía por referencia psicosocial. La práctica de escuchar los enfrentamientos con los principios de la reforma de la salud, por lo tanto, no permite la inserción del sujeto en el proceso de atención, e incluso hacer caso omiso de su discurso como una expresión de su existencia-sufrimiento. Aunque contiene elementos del marco psicosocial en la práctica la escucha se limita a abordar el sufrimiento mental sin reconocer a la persona que sufre. DESCRIPTORES: Enfermería. Salud mental. Servicios de salud mental. 


\section{INTRODUCTION}

The foundational principle of the Psychiatric Reform movement in Brazil is the new framework of mental healthcare services in replacement for the asylum model, a setting where the clinical practice was focused on the valorization of the subject and his/her needs. ${ }^{1}$

In such perspective, the mental disease concept has been undergoing a deconstruction process and making way to a new form of perceiving the subject's madness as an existence-suffering reality in relation to the social body. The concept behind such approach is based on a psychic suffering perspective. $^{2}$

Within the boundaries of these discussions, new care mechanisms toward the subject in psychic distress have been arising. Among them, the present study highlights the therapeutic listening.

Therapeutic listening stands out as a resource that is still poorly employed by the majority of mental health professionals, either as a result of an individual option or due to a lack of knowledge concerning its operability in the practical area. In the nurses' standpoint, such fact is originated in the configuration of the services, where the concerns with the length of time of the care processes, as well as the reduction of the care time aimed at providing the medical prescription for psychotropic medicines, ${ }^{3}$ prevail.

Academic publications on therapeutic listening carried out in the nursing area show that such strategy is generally employed as a means and an end to the mental healthcare, either reflecting the relevance of the listening attitude to the common sense or expressing a wide array of nuances, based on several different theoretical frameworks guiding the therapeutic listening process. ${ }^{4}$ Within this context, the following question should arise: which theoretical framework guides the therapeutic listening in the clinical mental health care nursing?

The therapeutic listening is not only composed of a moment when individuals speak, but a device that produces sense, thus enabling the minimization of the anguish resulting from listening to one's own self, having the other as a mirror. ${ }^{3}$

According to the Ministry of Health, among several other actors involved in the historical process of building the Psychiatric Reform in Brazil, therapeutic listening stands out as a tool to cope with the subjective dimension of the psychic sickness. $^{3}$

Therefore, the present research is highly relevant in the sense that it problematizes the practice of the therapeutic listening under the psychoanalytical framework, hence broadening therapeutic care possibilities toward individuals experiencing psychic suffering. The proposed reflection becomes a necessity in face of practices guided by theoretical frameworks that exclude the subject from the care context, depriving him/her of the right to participate in the decisions concerning his/her own therapeutic process, even though the current practices are carried out within the context of the deinstitutionalization of madness. Hence, the aim of the present study was to comprehend the concept of therapeutic listening in the clinical mental health care nursing.

\section{METHOD}

The subjects of this qualitative study were nine nurses who worked in mental health services in the city of Mossoró, Rio Grande do Norte state, namely the Psychosocial Care Centers (CAPS) and the city's psychiatric hospital.

Inclusion criteria were: working as a nurse at the service and working directly with the subjects in psychic suffering. The adopted exclusion criteria were: being a nurse working at the service for less than six months; working only in the night shift or weekends; having a workload lower than 20 weekly hours; being on health, vacation, transference or strike leave.

Recruited subjects were visited at their workplace. Each of them received an invitation letter, which presented the phases of the research, the proposed theme, the object of the study, and an explanation of the data production process.

Data were collected by means of semistructured interviews, guided by the following questions: Which nursing activities do you carry out with patients in psychic distress? How do you listen to individuals in psychic suffering?

In order to safeguard the anonymity of the statements, each subject was identified as Nurse, followed by a number that does not correspond to the chronological order of interviews.

The French approach of the Discourse Analysis, represented by Michel Pechêux ${ }^{5}$, was the analysis methodology adopted.

The research proposal was submitted to the Research Ethics Committee of the Universidade do Estado do Rio Grande do Norte (UERN), and approved under protocol number 60577, CAAE 
04434712.6.0000.5294, on July 27, 2012.

\section{RESULTS}

The current appropriation of the listening process as a mental health care instrument has been thought only under the perspective of being a means to achieve other objectives. Such process does not provide the suffering subject with a voice. Such therapeutic practice is comprehended only as an information collection process aimed at handling the subject's needs under the format of an embracing moment. The following discourses ratify this conception:

[...] seek to be familiar with what he is not talking about, his behavior, what lies behind all this inheritance, this emotional burden he has. [...] then, to get information on the mother's pregnancy, how many brothers and sisters he has, if he is the oldest child, if he used to financially support the family at the moment such load of responsibility started. When you start asking about certain situations, then you find out, you start seeing how the life of that patient really is. You should not see a person out of a context (Nurse 2).

According to Nurse 8, [...] in this moment, an active search of the patient's reality is carried out, his space, his time, his behaviors, and then you can ask why the hygiene level is precarious, why he reports lack of sleep, why he affirms to hear voices, why he has visual hallucinations, then you see the whole process, the prevalent schedules. And it is right in this moment that you are able to duly refer him to a psychiatrist, if necessary, or even a psychologist, a psychoanalyst, or a physical educator, if there is one available.

The listening process stands out as a moment when lots of information are gathered; however, information on the life history of the subject in psychic suffering is often out of context.

It is a way of embracing, a way of embracing the patients [...] a way of dialoguing with them, of listening to them. For instance, this is how we listen to them. We come up with an issue [...], soap opera, for instance: 'are you watching that soap opera? What do you think about that woman, that actress' [nurse's speech], in order to learn how the patient sees the behavior of other people [...] If you ask her: "do you do that?" 'Oh, no, what do you think about it?' 'I think she's pretty, she is straightforward, I like her mood' [patient's speech]. Then, you start seeing that the patient wants to be that way, be authentic, she wants to be like that actress, but she does not have the courage to do so. [...] (Nurse 2).

In general, the studied reality showed that the subject in psychic distress is taken to the health services by family members. According to the interviewed individuals, the family is expected to be responsible for all information, without the presence of the patients in psychic suffering. Family members are held accountable as the major source of information, as they are not deemed to be sick. The following discourses point out such comprehension:

and you also talk to the family, carrying out a specific search with the family. And then we collect the patient's history [...] I refer the patient to the admission department, and proceed the interview only with the family (Nurse 1).

The same procedure is also used to compare the discourses of the patient and his family:

when they [patients] say they have a problem, we invite their families to come and then we talk to them about what is going on. We keep talking to them, observing both sides. As the patient has a mental disease, you have to hear both sides, sometimes it is hard [...] how can I say that [...] sometimes it's just hallucination, they may make things up [...]. And then we talk. We have to check out the family's standpoint (Nurse 6).

Whenever it is necessary to hospitalize a patient in the psychiatric hospital, the first step is to have an interview with the family. At the CAPS, when meetings are appointed with the families, the respective patients are not allowed to take part in the interviews.

Additionally, the nurses' discourses highlight that the problems reported in the conversations with the family are not always in harmony with the patient's complaints. Even so, the nurses value much more the demands of those who brought the patient in psychic suffering to the healthcare service than what those individuals have to say about themselves. Such practice is reaffirmed in the following statement:

We work with the patient's family, and listen to them. We listen to the patient's history, based on his complaints, and we listen to the family, based on their reports (Nurse 8 ).

In the discourses of the interviewees, it is also observed that although the clinical practice discourse is politically based on the Psychiatric Reform, the medicalization of the psychic distress is still the objective of therapeutic interventions. Some statements highlight a reductionist view of the mental health care and the risks of reaffirming the alienation of these subjects:

depending on what the patient displays. [...] 
Then you ask, 'Why do you think there is a bug in there? What is going on?' Then, you start showing her, you start arguing with her, showing that there is no bug in there, that she killed the bug while she was hallucinating. You try to get it from her, and she gets calmer. She got calmer and calmer, but we had to provide her with medication, you have to introduce the medication. She was quite anxious, she cried a lot, and we waited for her to calm down. We try to stimulate her own decision, hoping that she looks for it by herself, we try to give her an instrument that she can use against her own frenzy, so that she can find her way out. We cannot confront her, we can never confront the patient (Nurse 1).

These interventions are also observed in the medical prescription: the psychiatrist prescribes the medicine and we, at the nursing department, administer the medications orally, in accordance with the medical protocol. I also work toward listening to the demands of the mentally ill patient, his complaints, his clinical complaints, body complaints, dermatitis, gastroenteritis, also the illnesses caused by alcohol and other drugs, psychic disorders, hallucinations, deliriums, desires, anguishes, phobias, fears (Nurse 8).

The statements reveal some aspects of the nurses' professional background that are still very much rooted in the biomedical model. Therefore, such practice does not subsidize a model centered on the subject and his existence-suffering. According to the professionals, we are definitely not prepared at the university to cope with certain mental distress situations [...] theoretically, the mental heal th policy is very nice, but in the practical field [the nurse shows dissatisfaction by saying it out loud] it is really difficult (Nurse 6). The CAPS manual does not say a word on how the nurse should proceed. It's hard for us to deal with it in the practical field [...]. I'd say the mental healthcare academic background is more useful for us to get familiar with the diseases and the mental functions. [breathes nervously showing unbelief concerning such reality]. It's very poor, and our practice is even poorer (Nurse 9).

By means of the paraphrase device, the discourses reveal a certain degree of difficulty toward the outline of the role of these mental healthcare professionals, a fact that cause them to be bound to administrative tasks and those assignments directed to the patient's body care. According to interviewee 7, I usually work more in the administrative area and I organize and participate in the groups [...]. My director asked me to keep up with the groups [...] [the nurse lowered his voice]. Currently, I've been working with group therapy, every afternoon I handle group therapies (Nurse 7).

\section{DISCUSSION}

In theory, the Psychiatric Reform is comprehended as a social process that highlights and articulates four strategic dimensions addressing the changes proposed by the asylum model: the theoretical-conceptual or epistemological dimension, related to the deconstruction of the foundations of the traditional psychiatry, for instance, the understanding of the disease; the technical-care related dimension, encompassing the construction of a substitutive network to the asylum model as spaces of sociability, exchanges and productions of subjectivity; the juridical-political dimension, addressing the emphasis of the laws in ensuring mental health labor rights, family, social life and collective life conquests; and the sociocultural dimension, which seeks to generate transformations in the historically built social imagination of madness. ${ }^{6}$

As for the clinical practice, the Reform proposes a model that is articulated with the deinstitutionalization concept. This process seeks to deconstruct "[...] knowledge, practices, cultures and values grounded on the disease/hazardousness. Such deinstitutionalization framework requires the health practice to tear down common sense scientific and institutional responses and breakthrough the mechanical cause-effect correlation concerning the analysis of the constitution of madness, so that the problem can be dismantled and then recomposed, recontextualized and recomplexified". ${ }^{7: 93}$

Therefore, the clinical practice should not be aimed at outlining complaints and symptoms of subjects in nosological conditions, but at perceiving that the situations that cause them to seek the care service are the ones that originate their suffering. Therefore, such people need to be listened to, as psychic distress is more connected with the values of the individual and marked by issues that go beyond the physical plan, involving ethical, moral, religious, psychological, social, and culture aspects. ${ }^{8}$

Hence, in the scope of the Reform, the therapeutic listening is presented as a care device capable of relocating the focus of interventions, leaving the mental disease behind and heading to the understanding of the subject's existencesuffering. ${ }^{2}$

Nevertheless, the present study identified 
the listening practice only as a means to obtain information about the subject, bound to objective, yet incoherent data related to the patient's existence-suffering.

The authors also observed an emphasis on the listening process as a means to collect information that will instrumentalize the care itself. From this standpoint, two consequences may be apprehended. First, the patient remains in an objectified position, segregated from everything related to his desire and suffering. As the listening strategy is only intended to search for information, there is no difference whatsoever if such information is provided by the suffering subject or one of his family members. As a matter of fact, the family alone is expected to provide all necessary information, generally without the presence of the patient, as the family is comprehended as the holder of the capacity of providing true information on the patient and his suffering.

The second consequence of this apprehension of the listening strategy as a means to an end generates a distortion of understanding regarding its therapeutic approach, as the process is only aimed at providing information on the patient, when this information is actually related only to the patient's symptoms.

Based on the Psychiatric Reform, we understand that the suffering is expressed by the language, and only the language is able to elaborate on the suffering to be addressed. ${ }^{9}$

In the absence of a theoretical and methodological foundation that generates a change in the care practice, causing its focus to move from the disease to the existence-suffering, this care is still anchored in a clinical reference point that addresses the illness, the organic complaint and the medical diagnosis, resulting in the exclusion of the individual from the care process. ${ }^{4}$

In the studied reality, the listening practice is composed of a certain amount of conceptual elements that allow us to locate the strategy in the psychosocial framework. Such model, which comprehends the subject in psychic suffering based on a global perspective and taking into account his political, social, biological, cultural, and psychological factors, was born to oppose to the asylum model. Additionally, the strategy proposes that such individual takes part in the treatment process along with the professional team, with full autonomy to make decisions regarding his therapy. ${ }^{10}$

In the psychosocial model, the nursing prac- tice is grounded on the establishment of effective interpersonal relationships. This model helps the subject in psychic distress to carry out daily chores or perform daily activities. As a result, though, the nursing practice is turned into a mere motherhood process that contributes very little to the autonomy of such individuals. ${ }^{11}$

The clinical practice still shows several theoretical, conceptual and methodological gaps to be filled toward the implementation of the change in the asylum model. The reformist discourse displays, explicitly or implicitly, a severe criticism to the clinical practice developed by the psychiatric model and sees the latter as a reductionist and individualistic device that hinders the socialization of the patient.

"The trend that sought to overcome the reductionist and normatizing clinical practice in its classical sense aggravated the tension between the healthcare clinic and the healthcare policy, questioning basic principles of the traditional psychiatry, such as the diagnosis, the cure and the idea of the tutelage, which ascribed the subject-object intervention the acceptance of a single, universal subjectivity model."12:22

In this sense, the study identified the need for a reflection of the listening practice under perspectives other than the objectification of the suffering and the suffering patient. It is not enough to only tear the walls of the asylum down, we need to modify the relationships between patients and mental healthcare professionals. The adoption of another knowledge framework for the management of this relationship is an urgent matter, as the traditional psychiatric-based knowledge impregnated in both institutions and practices still prevail. ${ }^{13}$

The presuppositions of the Psychiatric Reform recommend the construction of bonds, as well as embracement and listening practice as essential tools toward mental healthcare, since such strategies safeguard people's right to participate in the decisions involving them. These technologies enable the comprehension of the psychic suffering based on the patients' standpoint, valuing their experiences and paying attention to their needs, including the different aspects that constitute this individuals' daily framework. ${ }^{14}$

Hence, in order to reach a fashion of clinical practice that values the experiences of the patient to the detriment of focusing on the disease, the understanding of the symptom and the singularity of the patient's demands is a must. Such procedure reflects the recognition of the ethical 
dimension of the subject, articulated with the patient's desire, allowing him to reinvent spaces and tools used in the mental health care carried out by the nursing practice. ${ }^{3}$

In order to ensure a type of care directed at these principles, a series of ethical-political actions are vital, namely: breakthrough the comprehension of the psychic suffering under a Cartesian perspective; acknowledge the desire dimension and its articulation with the "other" in the same suffering; recognize that the choices that determine the path of life are marked by the incidence of a division in the inscription of one's own unconscious, and that such inscription takes place by the subject's access into the language world. ${ }^{15}$

The mental healthcare professional, therefore, is summoned to endure the misery of the world, and to handle the sorrows society does not want to see, that is, its most radical "other", namely madmen, drug addicts, and suicidal individuals.

In this battle, a firm determination in face of an imposing social reality and its violence, exploitation and segregation is a crucial step. To cope with the misery of the world means " $[. .$.$] to$ access its conditioning discourse, even if it is only to protest". ${ }^{16: 516}$ "Aware of it or not, this is what mental healthcare professionals do". ${ }^{16: 516}$

The theoretical and methodological background of the psychoanalysis framework promotes the advancement of the reconstruction of the mental healthcare model. The milestones of this framework are as follows: the recognition of the ethical dimension of the subject, articulated with his desire, a fact that grounds the reinvention of care spaces and tools; and the conception of the listening process as a therapeutic strategy in itself, and as such, a pathway toward the metabolization of traumatic experiences. ${ }^{17}$

Psychoanalysis is based on a transference experience, the identification of a hypothetical knowledge; as such, the listening practice provides spaces for individuals in psychic pain to speak up and be listened to, an action that provides them with opportunities to assign meanings to their experiences, their demands for help, their history and their concrete existential conditions.

\section{FINAL CONSIDERATIONS}

Therapeutic listening in the clinical mental health care nursing is still currently comprehended under the psychosocial framework, that is, as a mere way of collecting information on patients in psychic suffering. In practice, patients are generally deemed to be incapable of producing true information about themselves and their suffering, and such reality is clearly manifested whenever professionals do not differentiate the listening of both the subjects and their families, thus denying the therapeutic character of the listening strategy.

The current practice of the listening strategy has only been offering a preference for information that objectifies the individual, his suffering and his care needs. Based on the theoretical framework identified by this practice, although the nursing area does show a careful concern regarding the search for information on the environment the individual lives, it leaves the subjectivity of his discourse out of the equation.

Hence, the listening practice points out that the language is apprehended in its literal form based on a rationality that is paradoxically denied to the same subjects treated by the mental healthcare network.

In this sense, the adoption of a political discourse committed to the Psychiatric Reform and the development of a listening practice shaped under the traditional models identified by the present research forces the Reform to be stuck at the asylum model.

As an alternative to the psychosocial framework, the psychoanalytical framework promotes a listening strategy that is deemed to be therapeutic, a strategy aimed at levering the suffering subject to a leading position in the production of care. The incorporation of this framework by the nursing care implies the consideration of this individual as a carrier of truths, rather than someone deprived of reason. The employment of such framework provides the subject with the possibility of revealing truths about himself, a strategy that is capable of subsidizing the nursing clinical care in the mental health practice.

Psychoanalysis has its own methodology, and demands those who make use of it to display the will to cope with its related issues by means of the analysis, as well as a more profound knowledge of its concepts and founding pillars. It also requires an academic background that is certified by accredited institutions, more specifically those institutions grounded on the Freudian psychoanalysis.

Such a framework is able to bring a series of contributions to mental healthcare services, as it deals with the spoken communication as a phenomenon that escapes both the objectification and the literal apprehension of meanings. As its 
proposals deem the spoken communication to be a non-transparent method, the listening strategy makes it possible for the subject in suffering to be levered to a leading condition in the care practice.

The justification for the emphasis given to the psychoanalysis in this study stems from the fact that such framework is still rarely employed by the nursing practice, but with a strong potential to resignify the discourses of the patient in psychic suffering, thus creating new approaches, in compliance with the principles of the Brazilian Psychiatric Reform.

\section{REFERENCES}

1. Guimarães AN, Borba LO, Larocca LM, Maftum M. Tratamento em saúde mental no modelo manicomial (1960 a 2000): histórias narradas por profissionais de enfermagem. Texto Contexto Enferm [online]. 2013 Abr-Jun [acesso 2014 Set 18]; 22(2):361-9. Disponível em: http://www.scielo.br/pdf/tce/ v22n2/v22n2a12.pdf

2. Amarante AL, Lepre AS, Gomes JLD, Pereira AV, Dutra VFD. As estratégias dos enfermeiros para o cuidado em saúde mental no programa saúde da família. Texto Contexto Enferm. 2011 Jan-Mar; 20(1):85-93.

3. Lima DWC, Silveira LC. A escuta no cuidado clínico de enfermagem ao sujeito em sofrimento psíquico: discursos e rupturas [dissertação]. Fortaleza (CE): UECE, Programa de Pós-Graduação em Cuidados Clínicos em Enfermagem e Saúde; 2012.

4. Lima DWC, Silveira LC, Vieira AN. Listening in the treatment of psychological stress: an integrative review. J Nurs UFPE. 2012 Set; 6(9):2273-80.

5. Orlandi EP. Análise do Discurso: princípios e procedimentos. $6^{\mathrm{a}}$ ed. Campinas (SP): Pontes; 2005.

6. Amarante $\mathrm{P}$, coordenador. Saúde mental, políticas e instituições: programa de educação à distância. Rio de Janeiro (RJ): FIOCRUZ; 2003.
7. Nicácio MFS. Utopia da realidade: contribuições da desinstitucionalização para a invenção de serviços de saúde mental [tese]. Campinas (SP): UNICAMP, Faculdade de Ciências Médicas, Programa de PósGraduação em Saúde Coletiva; 2003.

8. Kantorski LP, Pinho LB, Saeki T, Souza MCBM. Relacionamento terapêutico e ensino de enfermagem psiquiátrica e saúde mental: tendências no estado de São Paulo. Rev Esc Enferm USP. 2005 Mar; 39(3):1724.

9. Aguiar DT, Silveira LC, Dourado SMN. A mãe em sofrimento psíquico: objeto da ciência ou sujeito da clínica? Esc Anna Nery. 2011 Jul-Set; 15(3):622-8.

10. Püschel VAA, Ide CAC, Chaves EC. Modelos clínicos e psicossocial de atenção ao indivíduo e à família na assistência domiciliar - bases conceituais. Rev Esc Enferm USP. 2006 Jun; 40(2):261-8.

11. Brito TRJC. O trabalho em saúde mental: uma análise preliminar relativa à saúde dos trabalhadores dos serviços públicos. Rev Bras Saúde Ocup. 2008 Mai; 33(117):36-49.

12. Almeida PF, Santos NS. Notas sobre as concepções de clínica e ética na reforma psiquiátrica brasileira: impasses e perspectivas de uma prática em construção. Psicol Cienc Prof. 2001 Set; 21(3):20-9.

13. Bessa JB, Waidman MAP. Família da pessoa com transtorno mental e suas necessidades na assistência psiquiátrica. Texto Contexto Enferm [online]. 2013 Mar [acesso 2014 Set 18]; 22(1):61-70. Disponível em: http:/ / www.scielo.br/scielo.php?pid=S010407072013000100008\&script=sci_arttext\&tlng=pt

14. Mielke FB, Olschowsky A. Ações de saúde mental na estratégia saúde da família e as tecnologias em saúde. Esc Anna Nery. 2011 Out-Dez; 15(4):762-8.

15. Lacan J. O seminário livro 7: a ética da psicanálise. Rio de Janeiro (RJ): Jorge Zahar; 1997.

16. Lacan, J. Outros escritos. Rio de Janeiro (RJ): Jorge Zahar; 2003.

17. Dockhorn CNBF, Kother MMM, Werlang BSG. Desamparo e dor psíquica na escuta da psicanálise. Barbarói. 2007 Jul-Dez; 27(2):25-42. 